40 Hausen B, Heublein B, Vogelphol J, Von der Leyen H, Haverich A. Comparison of enoximone and piroximone in patients after mitral valve operation: a prospective and controlled study. I Cardiovasc Pharmacol 1992;19:299-307.

41 Vincent JL, Leon $M$, Berre J. The role of enoximone in the treatment of cardiogenic shock. Cardiology 1990:77(suppl 3):21-6.

42 Packer M, Carver JR, Rodehoffer RJ, Ivanhoe RJ, Dibianco R, Zeldis SM, et al. Effect of oral milrinone on mortality in severe chronic heart failure. $N$ Engl f Med 1991;325:1468-75.

43 Dibianco R, Shabetai R, Kostuk W, Moran J, Schlant RC, Wright R. A comparison of oral milrinone, digoxin, and their combination in the treatment of patients with chronic heart failure. N Engl $\mathcal{F}$ Med 1989;320 $677-83$

44 Curfman GD. Inotropic therapy for heart failure-an unfulfilled promise N Engl f Med 1991;325:1509-10.

45 Packer $\mathrm{M}$. Long term strategies in the management of heart failure: looking beyond ventricular function and symptoms. Am f Cardiol 1992;69:150-4G.

46 Pitt B. New approaches to therapy of cardiac failure. Current Opinion Cardiology 1992;7:404-7.

47 Goldstein RA, Gray EL, Dougherty AH, Nacarelli GV. Electrophysiologic effects of amrinone. Am f Cardiol 1985;56:25-8B.

48 Honerjager P. Pharmacology of positive inotropic phosphodiesterase inhibitors. Eur Heart f 1989;56:39-40B.

49 Hines R. Preoperative and postoperative use of inotropes in cardiac surgery. fournal of Cardiothoracic Anesthesia 1990;4(suppl 5):29-33.

50 Vincent JL, Leon M, Berre J, Melot C, Kahn RJ. Addition of enoximone to adrenergic agents in the management of severe heart failure. Crit Care Med 1992;20:1102-6.

51 Robinson RJS, Tcheervenkov C. Treatment of low cardiac output after aortocoronary bypass surgery using a combination of noradrenaline and amrinone. Foumal of Cardiothoracic Anesthesia 1987;3:229-33.

52 Olsen K, Kloya J, Fieldman A. Combination high dose amrinone and dopamine in the management of moribund cardiogenic shock after open heart surgery. Chest 1988;94:503-7.

53 Uretsky BF, Lawless CE, Verbalis JG, Valdes AM, Kolesar JA, Reedy PS Combined therapy with dobutamine and amrinone in severe heart failure. Chest 1987;92:657-62.

54 Murphy MB. The therapeutic role of drugs acting on cardiovascular dopamine receptors. Journal of Cardiotheracic Anesthesia 1990;4(suppl 1):23-6.

55 Van Trigt P, Spray TL, Pasque MK, Peyton RB, Pellom GL, Weschler AS The comparative effects of dopamine and dobutamine on ventricula mechanics after coronary artery bypass grafting: a pressure-dimensio analysis. Circulation 1984;70(suppl I): 112-7.

56 Kaplan JA, Guffin AV. The inodilators: an expanding role in the perioperative period. Foumal of Cardiothoracic Anesthesia 1990;4(suppl 1):27-31.

57 Maccioli GA, Lucas WJ, Norfleet EA. The intra-aortic balloon pump: review. Fournal of Cardiothoracic Anesthesia 1988;2:365-73.

58 Kantrowitz A, Tjonneland S, Freed PS, Phillips SJ, Butner AN, Sherman JL $\mathrm{Jr}$. Initial clinical experience with intra-aortic balloon pumping in cardiogenic shock. IAMA 1968;203:135.

59 Kantrowitz A, Freed PS, Cardona RR, Gage K, Marinescu GN, Westveld AH, et al. Initial clinical trial of a closed loop, fully automatic intra-aortic balloon et al. Initial clinical trial of a closed loop,
60 Alderman JD, Gabliani GI, McCabe CH, Brewer CC, Lorell BH, Pasternak $\mathrm{RC}$, et al. Incidence and management of leg ischemia with percutaneous wire guided intraortic balloon catheters. 9 Am Coll Cardiol 1987;9:524.

61 Kapoor AS. Application of intra-aortic balloon pump for circulatory support. In: Kapoor AS, Laks H, Schroeder JS, Yacoub MH, eds. Cardiomyopathies and heart-lung transplantation. New York: McGraw Hill, 1991.

62 Abiomed Inc. The pulse. Danvers, Massachusetts: Abiomed, 1992.

63 Moore CH, Dailey JW, Canon DS, Rubin JMO. Non-pulsatile circulatory support in 90 cases. ASAIO Trans 1992;38:M627-30.

64 Pae WE. Ventricular assist devices and total artificial hearts: a combine registry experience. Ann Thorac Surg 1993;55:295-8.

65 Farrar DJ, Hill JD. Univentricular and biventricular Thoratec VAD suppon as a bridge to transplantation. Ann Thorac Surg 1993;55:276-82.

66 McCarthy PM, Portner PM, Tobler HG, Starnes VA, Ramasamy N, Oyer PE. Clinical experience with the Novacor ventricular assist system. I Thorac Cardiovasc Surg 1991;102:578-87.

67 Marks JD, Karwande SV, Richenbacher WE, Jones KW, Doty DB, Millar $\mathrm{RC}$, et al. Perioperative mechanical circulatory support for transplantation. fournal of Heart and Lung Transplantation 1992;11:117-28.

68 Mulcahy D, Fitzgerald M, Wright C, Sparrow J, Pepper J, Yacoub M, et al. Long term follow up of severely ill patients who underwent urgent cardiac Long term follow up of severely ill pat.
transplantation. BMF 1993;306:98-101.

69 Poirier V. The quest for the permanent LVAD: we must continue, we must push forward. ASAIO Trans 1990;36:787-8.

70 Pennington DG. Circulatory support at the turn of the decade: a clinician's view. ASAIO Trans 1990;36:M126-31.

71 Miller LW. Mechanical assist devices in intensive cardiac care. Am Heart 1991;121:1887-92.

72 Tanaka K, Sato T, Kondo C, Yada I, Yuasa H, Kusagawa M, et al. Hematological problems during the use of cardiac assist devices: clinica experiences in Japan. Artif Organs 1992;16:182-8.

73 Bianchi JJ, Swartz MT, Raithel SC, Braun PR, Illes MZ, Barnett MG, et al. Initial clinical experience with centrifugal pumps coated with the carmed process. ASAIO Trans 1992;38:M143-6.

74 Reedy JE, Pennington DG, Miller LW, McBride LR, Lohmann DP, Noede NR, et al. Status 1 heart transplant patients: conventional versus assis device support. Foumal of Heart and Lung Transplantation 1992;11:246-52.

75 Daniel MA, Lee J, LaForge DH, Chen H, Billich J, Miller PJ, et al. Clinical evaluation of the Novacor totally implantable ventricular assist system current status. ASAIO Trans 1991;37:M423-5.

76 Johnson KE, Liska MB, Joyce LD, Emery RW. Registry report. Use of tota artificial hearts: summary of world experience, 1969-1991. ASAIO Tran 1992;38:M486-9

77 Liska MB, Johnson KE, Emery RW. Current functional status of Symbio total artificial heart recipients after transplantation. ASAIO Trans 1992;38: 804-7.

78 Reedy JE, Swartz MT, Lohmann DP, Moroney DA, Vaca KJ, McBride LR, et al. The importance of patient mobility with ventricular assist device support. ASAIO Trans 1992;38:M151-3.

79 Ott RA, Mills TC, Eugene J, Gazzaniga AB. Clinical choices for circulatory assist devices. ASAIO Trans 1990;36:792-8.

(Accepted 21 May 1993)

\title{
Structural adjustment: the wrong prescription for Africa?
}

\author{
Dorothy E Logie, Jessica Woodroffe
}

\section{Health Centre, Earlston, Berwickshire Dorothy E Logie, general practitioner}

\section{Christian Aid, PO Box 100, London SE1 7RT Jessica Woodroffe, policy officer}

Correspondence to: Dr Dorothy E Logie, Cheviot View, Bowden, Melrose TD6 0ST

BMF 1993;307:41-4
It is the privilege of the rich to watch catastrophes from a balcony. Giraudoux.

As Africa emerges from the "lost decade" of the 1980 s it seems to be plunging into an even deeper quagmire of debt, ecological devastation, drought, and disease. Meanwhile we in the North watch the catastrophe, safe on our balconies, apparently unaware that our actions, and those of the institutions who represent us, are a major contributing factor to the continent's downward spiral of economic and social decline.

For years we have failed the ordinary people of Africa. Cast in the popular imagination of a bottomless pit for Western charity, the reality is that Africa, despite its increasing poverty, now transfers to the rich North $\$ 10$ billion a year, ${ }^{1}$ half of the debt interest due. Africa is not a lost cause: the people of Africa have shown resilience with a number of vibrant and innovative projects, communal associations, and small enterprises; they have struggled tenaciously to maintain their standards of living in the face of disasters. Africa can recover. What is required is urgent debt relief, fairer terms of trade, more democratic and transparent government, and economic programmes which are designed by and for African people rather than the rich in the North.

Malnutrition claims the lives of 11000 children each day, and exposure to disease is heightened by the fact that two thirds of all Africans do not have access to clean water for cooking and drinking. Sub-Saharan African countries are currently spending $50 \%$ more on servicing their debt than on the health and education of their children ${ }^{2}$ and less now on health per capita than they did in $1980 .^{3}$ As Africa's creditors, we should find this weighing heavily on our consciences. Despite paying out more than $\$ 1300$ billion between 1982 and 1990 , debtor countries are now $61 \%$ more indebted than they were in $1982 .{ }^{4}$

\section{How structural adjustment policies came about}

The story of Africa has not always been one of doom and gloom. During the 1960s and 1970s progress in education and health care was impressive. African governments consistently allocated a higher share of their gross national product to education and health than any other developing region except the Arab. states. ${ }^{3}$ The population with primary education doubled from $36 \%$ in 1960 to $79 \%$ in 1980 . From a meagre total of 1000 university graduates in 1960 , Africa was producing 7.0600 graduates 29 years later. ${ }^{3}$ Similar progress was made in health care, control of infectious diseases, hospitals, rural clinics, and community trained health workers. Child mortality more than halved between 1960 and 1990 (an achievement which took more than a century in the industrial world)..$^{5}$ The continent rode on a wave of hope. 
The 1980s, however, brought global economic crisis, generated by huge rises in oil prices and rapidly rising interest rates and made worse by deteriorating prices for Third World exports, protectionism in industrialised countries, drought, civil war, poor leadership in Africa (which put military spending before poverty reduction), and the explosion of AIDS. Countries in economic recession were expected to pay more and more in debt servicing. Most countries failed to meet the demands.

The industrialised North responded by demanding structural adjustment programmes (SAPs) designed by the International Monetary Fund and World Bank in return for debt rescheduling. Thirty six governments have now initiated a total of 241 programmes. ${ }^{3}$ Most debt relief, overseas aid, and investment is dependent on debtor countries agreeing to the implementation of these programmes. The need for the "World Bank seal of approval" has meant that structural adjustment programmes have dominated economic policy making in the Third World for over a decade.

\section{What is structural adjustment?}

The structural adjustment programme package includes trade liberalisation, devaluation, the removal of government subsidies and price controls, "cost recovery" in health and education, privatisation, a credit squeeze, and increased interest rates. According to the World Bank and International Monetary Fund, the adjustment package will restore economic growth and so ultimately lead to poverty reduction. Critics argue that in fact the programmes are designed to meet the needs of the industrialised countries by ensuring that debt is repaid and encouraging Third World countries to export cheap raw materials.

A bitter intellectual argument rages over whether such policies can sustain long term economic growth. Though most experts agree that some change was needed, there is increasing evidence, not least from the World Bank itself, that structural adjustment programmes have failed even on narrow economic criteria. ${ }^{6}$ They have been even less successful in reducing the poverty of those who gained nothing from the debt in the first place. ${ }^{3}$

\section{The medical and social consequences of SAP}

The results of structural adjustment programmes for the poor are usually rapid price rises, especially for food and transport, and the introduction of school and medical fees-while at the same time wages fall and unemployment increases. Land that used to produce food is now used to boost exports. There is an obsession with "things" rather than people-things like capital, credit, and gross national product. This "earn more-spend less" philosophy has put the entire social fabric of Africa at risk. The "cure" has been likened to bad doctors who prescribe the same medicine for all ailments to all patients. Country after country throughout Africa has relapsed into increasing illiteracy, rising child mortality, and increasing malnutrition and has seen a recrudescence of diseases (like measles, cholera, and tuberculosis). Malaria, once subdued, is returning as a major hazard. ${ }^{\prime}$

\section{Examples of the effects of adjustment ZIMBABWE}

The recent experience of Zimbabwe is perhaps typical of many adjusting countries. After independence in 1981, the new government improved rural health by setting up a network of peripheral clinics. Impressive achievements were made in nutrition,

\section{Effect of structural adjustment on women} and children

Women and children in particular have been adversely affected by adjustment programmes, bearing the brunt of the costs.

- Women's workload is increased. With cuts in health and education services, they have to act as unpaid nurses and teachers. More time is spent trying to make a reduced budget meet household needs. Already African women may work between 16 and 18 hours daily'

- Privatisation of land rights has displaced the small farmer (often a woman). The income from cash crops, promoted under a structural adjustment programme, is usually controlled by men; previously, produced food would have been the woman's domain

- The removal of subsidies on basic food prices, and fewer meals, results in inadequate nutrition. Two thirds of African women suffer iron deficiency in pregnancy'

- Women are particularly affected by cuts in health care (including family planning), by new charges, and by less accessible health care

- African women are 50 times more likely to die in childbirth than women in the North'

- Education cuts and the introduction of fees result in girls rather than boys being removed from school. Cuts in adult education are particularly damaging for women

- There has been a huge increase in the number of female heads of household as men depart to seek work in cities

- Child abandonment, delinquency, and street gangs increase as families cease to cope and disintegrate

- In times of high unemployment, women are usually the first to be pushed out of the work force

immunisation, and literacy. With child mortality reduced and life expectancy increased, Zimbabwe's record was praised in the 1981 United Nations Development Programme's human development report. During 1991, a cost recovery programme was initiated as part of an economic structural adjustment programme. That same year the country experienced extensive drought, and food had to be distributed to over half the population; both factors heavily strained resources. Health expenditure fell by $20 \%$ and spending on education by $14 \%$.

Charges were introduced for medical treatment, and patients above the minimum income were obliged to pay for their drugs and operations. Despite the establishment of a social development fund, intended as a "safety net" for the poor, many could no longer afford health care. The attendances at one rurat clinic fell by $39 \%{ }^{7}$ The number of babies born before arrival at Harare Central Hospital increased by one third in the six months following the introduction of the programme, and-although it is difficult to attribute exact causation (with AIDS an additional factor)maternal deaths in Harare have doubled in the past two years. ${ }^{8}$

At a time when the government needs all the experienced and skilled staff it can find, there has been a considerable "brain drain" of senior technical and managerial staff. Nurses, midwives, and 200 doctors have left the country since 1991. Drugs, dressings, needles, diagnostic kits are all in short supply and broken medical equipment lies unrepaired. In the past few months the Hospital Doctors Association of Zimbabwe has warned that the health service is in danger of collapse. ${ }^{9}$ 


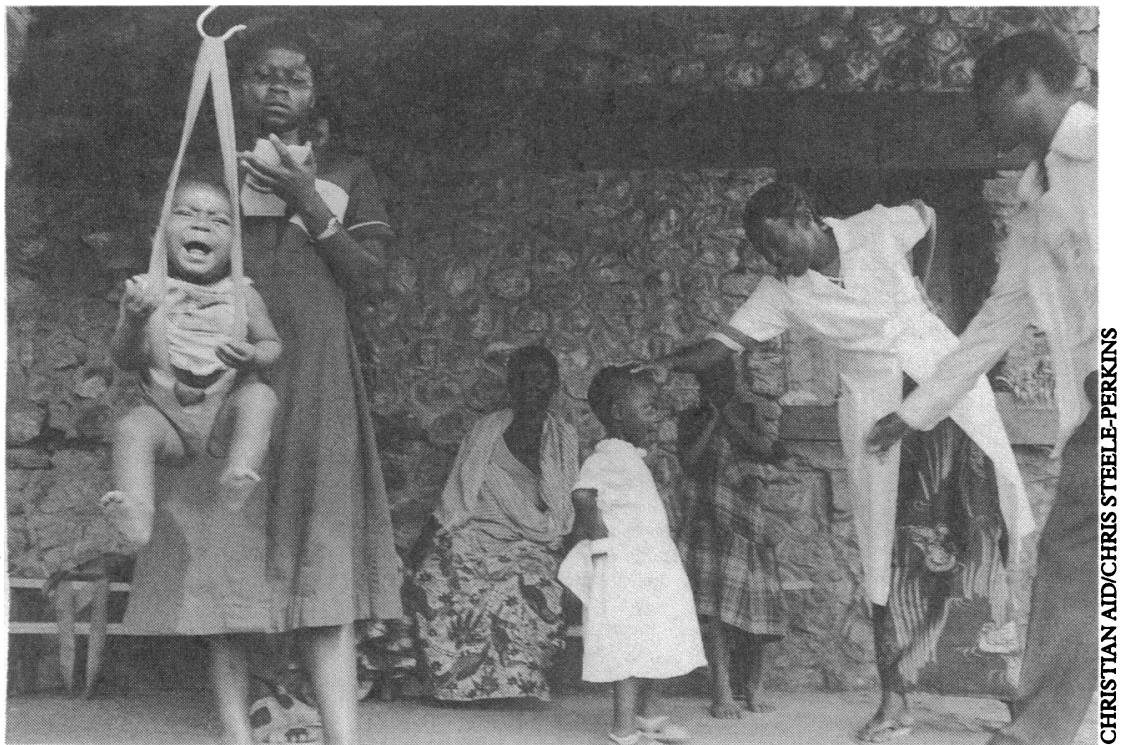

The health centre at Regetse, Zaire. During the 1960 s and 70 s progress in health care in African countries was impressive

ZAMBIA

In 1991 Zambia provided an example of a peaceful transition to multiparty democracy after 27 years of one party rule. But Zambia's fragile democracy is undermined by a huge debt and a recently introduced structural adjustment programme. Half of the $\$ 7.5$ billion debt has been written off or rescheduled, but only in return for a programme that aims to allow market forces to run the economy unrestrained. Zambia's health, education, and transport services are in a sorry state. Malnutrition now affects half of under $5 s$ and nearly a third of the adult population. On top of this the structural adjustment programme includes the removal of food subsidies - the price of maize (Zambians' basic food) has increased by $500 \%$ while 20000 public sector workers have been sacked. Even less money is now available for public services. ${ }^{10}$

\section{Alternative strategies for Africa \\ Extracts from African Alternative Framework to $S A P s,{ }^{16}$ one of the focal points for the development of an African alternative to structural adjustment pro- grammes. \\ - The ultimate goal of development in Africa is the overall wellbeing of its people through a sustained improvement in their living standards}

- Development should be the organic outcome of a society's value system, its perceptions, its concerns, its endeavours

- It is necessary to ensure the education and training, health, wellbeing, and vitality of the people so that they can participate fully and effectively in the development process

- The attainment of food self sufficiency is the first goal for Africa to strive for

- The poor should have access to factors of production, especially land, employment opportunities, and improved distribution of national wealth

- Clear objectives on the management of the environment are needed to ensure survival and wellbeing of present and future generations

- The pursuance of national and regional self reliance is vital

- Africa has to break the apron strings of dependence on a limited number of cheap primary commodities for export
SENEGAL

Senegal was one of the first African countries to undertake a structural adjustment programme, which was implemented in the early 1980 s. Since then there have been four programmes, each of which included massive cuts in public expenditure. Civil servants, teachers, nurses, and factory workers have all been laid off. Health spending as a proportion of gross national product dropped between 1978 and 1988, and per capita spending on health fell in the decade up to 1988-9. As usual the poor were hit hardest by these cuts, and the decade saw an increase in a number of diseases, including malaria, tuberculosis, and diarrhoea. ${ }^{11}$

\section{Wider effects of adjustment}

The reduction in expenditure on health and education and, in particular, the removal of food subsidies, have caused popular discontent, with the attendant risks of destabilisation, in so-called "IMF food riots"for example, in Nigeria, Zambia, Morocco, and Côte d'Ivoire. Increasingly, African governments are being expected to democratise, but structural adjustment programmes are undermining these efforts. The very legitimacy of the state may be eroded as the implementation of adjustment shifts the locus of authority and responsibility away from African capitals to international institutions.

\section{What can be done?}

The first step towards a solution is to reduce the outstanding debt burden. Debt relief initiatives have resulted in some short term palliation, but so far less than 3\% of total African debt has been cancelled. Moreover, there has been a failure to address the considerable amount of debt owed to the World Bank and International Monetary Fund, which now absorb $36 \%$ of total debt service payments. ${ }^{1}$ Governed by immutable laws, they cannot currently forgive debt; they can only delay its repayment. A major problem with all debt reduction schemes has been that they are linked to adjustment programmes. America's latest offer to cancel $50 \%$ of debt to the very poorest African countries is conditional on their acceptance of such programmes. ${ }^{12}$

The second step is to make sure that adjustment programmes put the needs and aspirations of the poor at the centre of any planning. In the past few years UNICEF, Oxfam, Christian Aid, and other nongovernment organisations have called for such reforms. The United Nations Development Programme's 1990 human development index derives from such a people centred approach. ${ }^{5}$ Though some change has taken place in the rhetoric, particularly of the World Bank, ${ }^{13}$ it is vital to maintain pressure to ensure that reforms are put into practice.

A total of 134 countries have ratified the UN Treaty on the Rights of the Child and should now bring their legislation in line with the aims of the treaty. ${ }^{14}$ Enforcing article 24 of the convention (the right of children to health care) and article 28 (right to education) may be one way of exerting pressure on the World Bank, the International Monetary Fund, and governments. Dr Richard Jolly, deputy director of Unicef, will put this point strongly to the G7 summit (the rich nations who largely control the fund) which meets in Tokyo on 7 July.

Health is the theme of this year's World Bank World Development Report, also to be launched on 7 July. ${ }^{15}$ The report's consideration of structural adjustment programmes is inadequate and the launch will provide an occasion for the medical profession to examine the World Bank's record on health outcomes. As well, 
1994 will mark the 50th anniversary of the Bretton Woods agreement, where the bank and fund were first conceived. The international spotlight will be on these organisations, providing another chance to draw attention to the damaging effects of structural adjustment programmes.

But reform of structural adjustment programmes should go further than just ameliorating the adverse impact on the poor. The right of international institutions to control the destiny of others should be questioned. Decisive action is needed if the development efforts of a continent are not to be thwartedaction which must start with a resolution of the debt crisis and finish with development which improves the lives of all. A clear message should be sent to governments and international institutions, who speak in our name, that we will no longer tolerate the imposition of policies which undermine rather than promote the wellbeing of the people of Africa.

Medical Action for Global Security (MEDACT), 601 Holloway Road, London N19 4DJ, is organising an international conference on 17 November 1993 in London on the human consequences of international debt. The programme is available from MEDACT.

1 Oxfam. Africa make or break. Oxford: Oxfam UK, 1993.

2 Unicef. The state of the world's children. Oxford: Oxford University Press, 1993.

3 Comia GA, ed. Africa's recovery in the 1990s. Florence: Unicef, 1992:19.

4 George S. The debt boomerang. London: Pluto, 1992:xvi.

United Nations Development Programme. Human Development Report 1992. Oxford: Oxford University Press, 1992:39.

6 Elbadawi T. World Bank Adjustment Lending and Economic Performance in Sub-Saharan Africa in the 1980s: a comparison of early adjusters, late adjusters, and nonadjusters. Policy Research working papers WPS 1001, Country Economics Department. The World Bank, Washington. October 1992

7 Logie D. Zimbabwe: Health or debt. Lancet 1993;341:950.

8 Unicef. Structural adjustment in Zimbabwe. Harare: World Bank Mission Library, 1992.

9 Bail out Harare Hospital from crisis. Herald (Zimbabwe). 1993 Jan 25:5.

10 Nyakutemba E. Getting vocal. New Internationalist. 1993;April:30.

11 Gouvernement du Senegal, Unicef. Analyse de la situation de l'infant et de la femme au Senegal. Dakar: Unicef. 1991.

12 Brummer A. US offers to write-off half debt of poorest countries in Africa as policy shifts to relieve "crushing burdens." Guardian 1993 May 14:15, col $4-6$.

13 Hultman T. World Bank signals U-turn on African Aid policy. Guardian 1993 May 24:8: col 7

14 Unicef. World summit for children. New York: Unicef, 1990

15 World Bank. Development report. London: World Bank Office, 1993.

16 UN Economic Commission for Africa. The African alternative framework to structural adjustment programmes for socio-economic recovery and transformation. Addis Ababa: UNECA, 1989:9-15.

\title{
Health, humanitarian relief, and survival in former Yugoslavia
}

\author{
Sir Donald Acheson
}

\begin{abstract}
Since the World Health Organisation's effort in former Yugoslavia started in July 1992 it has been concerned with the public health policies of survival. It has provided advice to the United Nations High Commission for refugees, helped the voluntary agencies coordinate their work, assessed health needs, and provided practical help in the field to all parties to the conflict. Three features of the Bosnia war have particularly deplorable effects on health: ethnic cleansing, deliberate attacks on hospitals, and systematic rape. The WHO's response has included initiatives in nutrition, winter survival, and medical supplies. This experience shows that the WHO can have a useful role complementary to that of other agencies in situations where the basic elements for survival of the population are seriously compromised by war.
\end{abstract}

In June 1992 I received an urgent call from Jo Asvall, the World Health Organisation's regional director for Europe, to go to Yugoslavia to be his special representative. My immediate objectives were to provide public health advice to the United Nations High Commission for Refugees-which is the lead UN agency in humanitarian relief - and to help coordinate the work of the non-governmental agencies, particularly in relation to the distribution of medical supplies.

Here I say a little about the war in Bosnia and how it affects health and health care, then deal with the WHO's response to the war, and finally try to draw some lessons for the future.

Department of Public

Health and Policy, London

School of Hygiene and

Tropical Medicine,

London WC1E 7HT

Sir Donald Acheson

Based on a lecture given in May 1993 at the London

School of Hygiene and

Tropical Medicine.

$B M \Im 1993 ; 307: 44-8$

\section{Basic elements of survival}

In Britain we are concerned with the health problems of a middle aged society-coronary heart disease, cancer, osteoarthritis, obesity, and so on. In the former Yugoslavia we were concerned with the public health policies of survival itself. The basic elements required to sustain human life are peace, air, water, food, and shelter-plus, for a minority, medical and the United Nations protected areas there was a shortage of all these elements except good fresh air. In particular there were major shortages of medical supplies, including the essentials for emergency surgery and medicines for chronic diseases. Damage to the public water supplies needed evaluation in many areas. Urgent planning was also needed to help people survive the winter, and a system was needed to monitor health in those areas where the prewar arrangements no longer worked.

Even if peace came immediately it was obvious that the state of the public health was so fragile and unstable that a WHO presence would be needed for at least a year.

\section{General background}

Before its break up the Federation of Yugoslavia comprised some 23 million people living in a beautiful country of which more than three quarters is mountainous. Except on the Adriatic coast the climate is continental with hot summers and in many places bitter winters.

The federation consisted of six republics: Slovenia, Croatia, Bosnia-Herzogovina, Serbia, Montenegro, and Macedonia-and two local autonomous areas (Volvodina and Kosovo) within Serbia. The areas with the most serious health problems at present are those directly facing the destructive impact of the war. These are virtually the whole of Bosnia and Herzogovina, including Sarajevo, the UN protected areas, and an additional fringe of Croatia bordering Bosnia and Serbia.

Outside this central area there has been little or no supplies. Even last summer in many parts of Bosnia

damage to buildings, water supplies, or other public utilities, but the health care system has not escaped. Economic collapse and hyperinflation and the influx of refugees have brought about serious shortages of medical supplies and curtailment of health services.

Serbia itself has suffered no invasion or any structural damage within its borders. Its burdens are its share of refugees, the many military casualties sent back from Serbian Bosnia to Belgrade for treatment, and the increasing pressure of sanctions. 